\title{
STUDI KOMPARASI HASIL BELAJAR SISWA YANG MENGGUNAKAN AURORA 3 DIMENSI PRESENTATION DENGAN SISWA YANG MENGGUNAKAN MEDIA ENGINE TRAINER PADA KOMPETENSI MENJELASKAN KONSEP MOTOR BAKAR
}

\author{
Teguh Pratikno', Ewo Termedi², Wahid Munawar ${ }^{3}$ \\ Depertemen Pendidikan Teknik Mesin, FPTK UPI \\ Jl. Dr. Setiabudi No. 207 Bandung 40154 \\ t_praktikno@yahoo.co.id
}

\begin{abstract}
ABSTRAK
Penelitian ini bertujuan untuk membandingkan belajar siswa yang menggunakan Aurora 3D dengan siswa yang menggunakan media engine trainer pada kompetensi menjelaskan konsep motor bakar. Metode penelitian yang digunakan adalah metode kuasi eksperimen dengan desain penelitian nonequivalent control group design, sampel penelitian menggunakan sampling purposive yang berjumlah masing-masing 20 siswa kelas TKR 4 sebagai kelompok eksperimen dan TKR 2 sebagai kelompok kontrol. Pengumpulan data dilakukan menggunakan tes pilihan ganda dengan lima pilihan jawaban. Hasil penelitian menunjukkan bahwa terdapat perbedaan hasil belajar siswa antara yang menggunakan Aurora 3D dengan siswa yang menggunakan engine trainer. Pemanfaatan media pembelajaran Aurora 3D dapat diimplementasikan dalam proses pembelajaran produktif.
\end{abstract}

Kata kunci: media pembelajaran, Aurora 3D, hasil belajar.

\section{PENDAHULUAN}

Sekolah Menengah Kejuruan (SMK) mempunyai peranan sebagai pencetak sumber daya manusia (SDM) yang siap memasuki dunia usaha/dunia industri (DU/DI). SMK merupakan jenis pendidikan menengah, yang secara khusus mempersiapkan lulusannya untuk menjadi tenaga kerja yang terampil dansiap latih serta kompetitif di DU/DI. Salah satu program yang ada di SMK yang dibutuhkan di dunia industri diantaranya program keahlian teknik kendaraan ringan.

Menurut Peraturan Pemerintah (PP) Republik Indonesia No 19 Tahun 2005 Pasal 26 ayat 3 tujuan dari SMK yaitu: untuk meningkatkan kecerdasan, pengetahuan, kepribadian, ahklak mulia, serta keterampilan untuk hidup mandiri dan mengikuti pendidikan lebih lanjut sesuai dengan kejuruannya.

SMK merupakan salah satu bagian dari pendidikan kejuruan dan bagian dari sistem pendidikan nasional. Tujuan SMK yaitu untuk mengembangkan kompetensi siswa pada bidang

\footnotetext{
${ }^{1}$ Mahasiswa Departemen Pendidikan Teknik Mesin FPTK UPI

${ }^{2}$ Dosen Departemen Pendidikan Teknik Mesin FPTK UPI

${ }^{3}$ Dosen Departemen Pendidikan Teknik Mesin FPTK UPI
} 
keahliannya, sehingga mampu memiliki keterampilan untuk hidup mandiri serta mempersiapkan tamatannya bekerja di dunia industri secara nasional maupun internasional.

Pencapaian tujuan pendidikan dipengaruhi oleh beberapa faktor, diantaranya adalah Proses Belajar Mengajar (PBM). Pada PBM terdapat unsur yang dapat menunjang tujuan pendidikan diantaranya adalah metoda pembelajaran dan media pembelajaran. Beberapa temuan yang penulis jumpai, dalam proses pembelajaran masih terpusat pada guru (teacher centered), PBM berpusat pada guru dan komunikasi yang terjalin searah dari guru kepada siswa. Penjelasan atau penuturan secara verbal oleh guru mengenai bahan pengajaran biasanya sering membosankan apabila cara guru menjelaskannya tidak menarik (Asyar, 2011). Dalam situasi ini tampilnya media akan mempunyai makna bagi siswa dalam menumbuhkan kembali perhatian belajar para siswa. Berdasarkan pertimbangan tersebut, diperlukan PBM yang diarahkan pada peningkatan keaktifan siswa dalam PBM sehingga tercipta proses belajar mengajar yang optimal.

Media pembelajaran turut menentukan hasil belajar siswa. Media yang berkembang saat ini yaitu penggunaan barang teknologi seperti komputer dan internet. Media pembelajaran yaitu terdiri dari: media visual, edia audio, media audio-visual, kelompok media penyaji dan edia objek dan media interaktif (Ruhimat, 2009). Media pembelajaran berbasis Information Comunication and Tecnology (ICT) terus menerus mengalami perkembangan yang begitu pesat, dan mencoba untuk memikat pengguna dengan tampilan yang lebih menarik, yaitu dengan tampilan tiga dimensi (3D). Dengan tampilan yang menarik diharapkan dapat menumbuhkan kembali perhatian belajar para siswa, sehingga dapat meningkatkan hasil belajar siswa.

Media pembelajaran lain yang biasa digunakan di sekolah adalah trainer alat pendidikan. Media ini dibuat untuk mengatasi keterbatasan objek maupun situasi sehingga pembelajaran tetap berjalan. Benda-benda tiga dimensi yang dapat disentuh dan diraba oleh siswa merupakan aplikasi dari media trainer. Trainer merupakan proses simulasi aplikasi membangun model dari sistem nyata atau usulan sistem, melakukan eksperimen dengan model tersebut untuk menjelaskan perilaku sistem, mempelajari kinerja sistem, atau untuk membangun sistem baru sesuai dengan kinerja yang diinginkan (Suryani, 2006). Salah satu fungsi pengunaan dari media adalah dapat menyajikan sesuatu yang sulit diadakan juga memberikan informasi yang akurat. Sehingga dapat meningkatkan motivasi, minat dan hasil siswa dalam belajar.

Hasil penguasaan konsep yang dicapai siswa dari pembelajaran terpusat pada guru terkategorikan rendah akibat dari kurang bervariasinya penggunaan media pendukung dalam 
PBM. Kondisi ini terlihat dari banyaknya siswa yang kurang mengetahui, mamahami, dan mengaplikasikan konsep pembelajaran yang telah dipelajari, indikatornya dari rendahnya hasil belajar. Hasil belajar yang dicapai siswa pada kompetensi menjelaskan konsep motor bakar belum mencapai hasil maksimal. Nilai ulangan tengah semester siswa belum mencapai Kriteria Ketuntasan Minimal (KKM), pada kelompok mata pelajaran produktif dengan nilai sebesar 7,5. Siswa dapat lulus jika memperoleh nilai lebih dari atau sama dengan 7,5. Namun kenyataannya di lapangan, tidak semua siswa dapat mencapai KKM pada mata pelajaran produktif kompetensi dasar menjelaskan konsep motor bakar. Perolehan nilai yang kurang tersebut harus secepatnya mendapat perhatian guru, agar siswa menguasai kompetensi yang dipelajarinya, yaitu menguasai konsep materi pembelajaran dengan memperoleh nilai yang lebih baik.

Hasil temuan dari peneliti sebelumnya, mengenai penggunaan multimedia dalam pembelajaran menunjukan adanya peningkatan hasil belajar siswa yang lebih baik. Terdapat perbedaan peningkatan hasil belajar siswa pada kompetensi memelihara kompresor peralatan refrigrasi menggunakan multimedia dibandingkan media trainer.

Media pembelajaran adalah segala sesuatu yang dapat menyalurkan pesan, dapat merangsang fikiran, perasaan, dan kemauan peserta didik sehingga dapat mendorong terciptanya proses belajar pada diri peserta didik. Multimedia presentasi adalah salah satu media pembelajaran berbasis komputer yang digunakan untuk menjelaskan materi-materi yang sifatnya teoritis, digunakan dalam pembelajaran klasikal dengan group belajar yang cukup banyak di atas 50 orang. Media ini cukup efektif sebab menggunakan multimedia projector yang memiliki jangkauan pancar cukup besar (Sudrajat, 2008). Kelebihan media ini adalah menggabungkan semua unsur media seperti teks, video, animasi, gambar, grafik dan sound menjadi satu kesatuan penyajian, sehingga mengakomodasi sesuai dengan modalitas belajar siswa. Dalam sudut pandang proses pembelajaran presentasi merupakan salah satu metode pembelajaran. Penggunaannya menempati frekuensi yang paling tinggi dibandingkan dengan metode lainnya. Berbagai alat yang dikembangkan telah memberikan pengaruh yang sangat besar bukan hanya pada pengembangan kegiatan praktis, dalam kegiatan presentasi pembelajaran akan tetapi juga pada teori yang mendasarinya. Proses belajar yang dialami siswa akan menentukan hasil belajar dan akan turut pula menentukan pencapaian tujuan pengajaraan. Hasil yang dicapai siswa dapat dilihat dari nilai akhirnya. 


\section{METODE PENELITIAN}

Metode yang digunakan dalam penelitian ini adalah metode eksperimen semu (quasi experimental design)dengan desain yang mempunyai kelompok kontrol, tetapi tidak dapat berfungsi sepenuhnya untuk mengontrol variabel luar yang mempengaruhi pelaksanaan eksperimen. Variabel luar yang dimaksud adalah variabel yang menjadikan kelompok kontrol pada penelitian. Penelitian yang dilakukan ini bertujuan untuk mengetahui bagaimana perbandingan media Aurora 3D Presentation sebagai media pembelajaran dengan media engine trainer ketika proses pembelajaran. Desain penelitian yang digunakan dalam penelitian ini adalah (Nonequivalent Control Group Design) yaitu menempatkan subjek penelitian ke dalam dua kelompok kelas yang terdiri dari kelompok eksperimen dan kelompok kontrol yang tidak dipilih secara acak. Kelas eksperimen diberikan perlakuan yaitu pembelajaran menggunakan media Aurora 3D Presentation (Shandika, 2012), sedangkan pada kelas kontrol diberikan perlakuan menggunakan dengan media engine trainer.

Populasi penelitian ini adalah siswa tingkat X bidang keahlian Teknik Kendaraan Ringan SMK Al-mufti Kabupaten Subang tahun ajaran 2012/2013 sebanyak 40 orang, terdiri atas dua kelas yaitu kelas X TKR 2 dan X TKR 4. Penarikan sampel dalam penelitian ini menggunakan teknik sampling purposive, yang digunakan dengan menentukan kriteria khusus terhadap sampel.

\section{HASIL PENELITIAN}

Hasil belajar siswa dapat diperoleh dari proses belajar mengajar yang diukur melalui tes. Kegiatan tes dilakukan dua kali yaitu tes sebelum pembelajaran dan tes setelah pembelajaran. Pengalaman belajar siswa sebelum proses belajar mengajar dapat diukur. Nilai tersebut menunjukkan tingkat pemahaman awal siswa terhadap materi pembelajaran, dari hasil tes ini dapat diketahui besarnya penguasaan terhadap materi pembelajaran dari pengetahuan awal menjadi penguasaan materi pelajaran. Hasil pada kedua kelas menunjukkan ada perbedaan pada kemampuan awal siswa sebelum menerima materi pembelajaran. Kelas Aurora 3D Presentation diperoleh skor tertinggi siswa yaitu 23, skor terendah 21,2, dengan rata-rata 21,86. Sedangkan untuk kelas engine trainer diperoleh skor tertinggi siswa yaitu 23,4, skor terendah 21,6, dengan rata-rata 22,41 .

Perbedaan yang tergambar pada hasil nilai, yang dilaksanakan setelah proses pembelajaran. Rata-rata nilai untuk kelas Aurora 3D Presentation lebih tinggi dibandingkan kelas 
engine trainer. Kelas Aurora 3D Presentation diperoleh skor tertinggi siswa yaitu 23,6, skor terendah 22,8, dengan rata-rata 23,13. Sedangkan untuk kelas engine trainer diperoleh skor tertinggi siswa 23,4, skor terendah 22,8, dengan rata-rata 22,99. Perbedaan hasil belajar siswa pada kelas Aurora 3D Presentation lebih tinggi dibandingkan kelas engine trainer. Kelas Aurora 3D Presentation rata-rata perbedaan hasil belajar setelah dilakukan pembelajaran dengan menggunakan Aurora 3D Presentation diperoleh sebesar rata-rata pre test $=21,86$ dan rata-rata post test=23,13. Sedangkan pada kelas pembelajaran dengan media engine trainer rata-rata pre test $=22,41$ dan rata-rata post test=22,99. Berdasarkan rata-rata perbedaan hasil belajar pada kompetensi menjelaskan motor bakar ini dapat disimpulkan, bahwa kelas Aurora 3D Presentation memperoleh hasil belajar lebih baik dari pada siswa yang belajar dengan menggunakan media engine trainer.

\section{PEMBAHASAN}

Pembahasan hasil penelitian dilakukan beberapa tahapan yaitu sebelum pembelajaran, proses pembelajaran, dan setelah pembelajaran. Melalui ketiga langkah tersebut diperoleh data hasil penelitian. Saat proses pembelajaran menggunakan media engine trainer siswa belajar seperti biasa, memperhatikan, mendengarkan penjelasan guru dan juga terdapat siswa yang melihat engine trainer juga bercanda dengan temannya. Pembelajaran dengan Aurora 3D Presentation dilaksanakan pada kelas eksperimen. Guru menyajikan presentasi menjelaskan materi tentang kompetensi menjelaskan konsep motor bakar, sedangkan siswa menyimak materi. Temuan di lapangan, para siswa terlihat lebih antusias belajar dengan menggunakan media Aurora 3D Presentation, meskipun ada dari mereka yang bercanda dengan temannya sambil memperhatikan materi.

Hasil belajar siswa dapat diperoleh dari proses belajar mengajar yang diukur melalui tes. Kegiatan tes dilakukan dua kali yaitu tes sebelum pembelajaran dan tes setelah pembelajaran. Pengalaman belajar siswa sebelum proses belajar mengajar dapat diukur. Nilai tersebut menunjukkan tingkat pemahaman awal siswa terhadap materi pembelajaran, dari hasil tes ini dapat diketahui besarnya penguasaan terhadap materi pembelajaran dari pengetahuan awal menjadi penguasaan materi pelajaran. Hasil pada kedua kelas menunjukkan ada perbedaan pada kemampuan awal siswa sebelum menerima materi pembelajaran. Kelas Aurora 3 D Presentation 
diperoleh skor tertinggi siswa yaitu 23, skor terendah 21,2, dengan rata-rata 21,86. Sedangkan untuk kelas engine trainer diperoleh skor tertinggi siswa yaitu 23,4, skor terendah 21,6, dengan rata-rata 22,41 .

Perbedaan yang tergambar pada hasil nilai, yang dilaksanakan setelah proses pembelajaran. Rata-rata nilai untuk kelas Aurora 3D Presentation lebih tinggi dibandingkan kelas engine trainer. Kelas Aurora 3D Presentation diperoleh skor tertinggi siswa yaitu 23,6, skor terendah 22,8, dengan rata-rata 23.13. Sedangkan untuk kelas engine trainer diperoleh skor tertinggi siswa 23,4, skor terendah 22,8, dengan rata-rata 22,99. Perbedaan hasil belajar siswa pada kelas Aurora 3D Presentation lebih tinggi dibandingkan kelas engine trainer. Kelas Aurora 3D Presentation rata-rata perbedaan hasil belajar setelah dilakukan pembelajaran dengan menggunakan Aurora 3D Presentation diperoleh sebesar rata-rata pre test $=21,86$ dan rata-rata post test $=23,13$. Sedangkan pada kelas pembelajaran dengan media engine trainer rata-rata pre test $=22,41$ dan rata-rata post test $=22.99$. Berdasarkan rata-rata perbedaan hasil belajar pada kompetensi menjelaskan motor bakar ini dapat disimpulkan, bahwa kelas Aurora 3D Presentation memperoleh hasil belajar lebih baik dari pada siswa yang belajar dengan menggunakan media engine trainer. Kelemahan pada penelitian ini adalah perlakuan pre test dan post test dengan jarak satu hari, sehingga hasil belajar siswa cenderung belum stabil.

Penggunaan Aurora 3D Presentation pembelajaran pada kompetensi menjelaskan motor bakar ini berpengaruh terhadap pemahaman yang dipelajari. Uraian materi pada Aurora 3D Presentation disajikan secara sistematis dan setiap informasi yang tampil bersifat membantu pemakaiannya, termasuk kemudahan pemakai dalam merespon, mengakses sesuai dengan keinginan, penggunaan bahasa yang sederhana dan menggunakan istilah yang umum memudahkan siswa dalam memahami materi yang dipelajari. Aurora 3D Presentation juga bersifat komunikatif, sehingga siswa dapat berinteraksi langsung dengan Aurora 3D Presentation tersebut tanpa harus melibatkan orang lain dalam memahami materi-materi yang ada di dalamnya, serta dapat memberikan semangat dan dorongan kepada siswa untuk mengetahui materi pembelajaran.

Aurora 3D Presentation pembelajaran pada kompetensi menjelaskan motor bakar menggunakan format presentasi, sehingga siswa dapat beradaptasi, karena tidak terlalu jauh berbeda dengan pembelajaran biasanya. Tampilan gambar pada Aurora 3D Presentation mempermudah siswa untuk memahami materi pelajaran. Presentasi yang dibuat dapat 
memberikan rangsangan untuk mempelajari materi yang ada. Penggunaan Aurora 3D Presentation ini juga dapat memberikan suasana yang belajar baru pada siswa, sehingga menimbulkan motivasi yang lebih pada siswa dalam belajar, sehingga yang akhirnya menambah penguasaan pada materi. Uji hipotesis penelitian yaitu dari hasil perhitungan diperoleh kesimpulan bahwa $\mathrm{H}_{\mathrm{o}}$ ditolak dan menggunakan $\mathrm{H}_{\mathrm{a}}$ artinya terdapat perbedaan hasil belajar siswa pada kelas yang menggunakan Aurora 3D Presentation dengan kelas yang menggunakan media engine trainer.

Akhirnya manfaat penggunaan media belajar bahwa salah satu fungsi utama dari media pembelajaran adalah dapat menambah kemenarikan tampilan materi sehingga meningkatkan minat dan motivasi siswa serta mengambil perhatian siswa untuk fokus dalam proses pembelajaran (Asyar, 2011). Faktor dalam pemilihan media yang tepat dan syarat dari media pembelajaran adalah dapat mempertimbangkan faktor acces, cost, technology, interactivity, organization, dan novelty (Arsyad, 2009). Sedangkan syarat-syarat media yang akan dipilih visible, intresting, simple, useful, accurate, legitimate, structure. Dengan demikian, kekurangan yang terdapat dari media engine trainer yang hanya dapat menampilkan persepsi indera mata, ukurannya terbatas dan hanya dapat dilihat oleh sekelompok siswa bisa ditanggulangi oleh Aurora 3D Presentation.

Pembelajaran dengan menggunakan Aurora 3D Presentation terbukti mempunyai peran yang cukup baik dalam menerapkan prinsip pembelajaran tuntas dan pembelajaran individual sesuai tuntutan kurikulum. Penggunaan Aurora 3D Presentation pembelajaran pada kompetensi menjelaskan motor bakar ini lebih baik dibandingkan dengan menggunakan pembelajaran dengan menggunakan media engine trainer.

\section{KESIMPULAN}

Kesimpulan penelitian ini yaitu terdapat perbedaan hasil belajar siswa yang menggunakan Aurora 3D Presentation dengan siswa yang menggunakan engine trainer pada kompetensi menjelaskan konsep motor bakar. Terdapat peningkatan hasil belajar siswa yang menggunakan Aurora 3D Presentation pada kompetensi menjelaskan konsep motor bakar. Terdapat peningkatan hasil belajar siswa yang menggunakan engine trainer pada kompetensi menjelaskan konsep motor bakar. 


\section{DAFTAR PUSTAKA}

Asyar, R. (2011). Kretaif Mengembangkan Media Pembelajaran. Jakarta: Gaung Persada.

Arsyad, (2009) Media Pembelajaran. Jakarta: PT. Raja Grafindo Persada.

Ruhimat, T. (2009). Kurikulum dan Pembelajaran. Bandung: Jurusan Kurtekpend FIP-UPI.

Sandika, (2012). Aurora 3D Presentation alternatif Media Pembelajaran Berbasis ICT. [Online] Tersedia: http//Aurora 3D Presentation alternatif Media Pembelajaran Berbasis ICT.html [14 Januari 2012].

Suryani, E. (2006). Pedoman dan Simulasi Media Pembelajaran. Bandung: Alfabeta.

Sudrajat. (2008). Sumber-Sumber yang Mempengaruhi Teknologi Pembelajaran. [Online] Tersedia: http//neozonk.blogspot.com/2007/11/ rangkuman-buku-media-pembelajarandan-sumber-belajar.html [17 November 2010]. 